\section{THE PLACE OF NORMAL PSYCHOLOGY IN MEDICAL EDUCATION.}

To the Editor of THE LANCET.

SIR, - In your issue of June 19th you publish a report of the Education Committee of the General Council of Medical Education and Registration, in which it is stated that the majority of the bodies consulted hold that "some instruction" in normal psychology "should be given by the lecturer in mental diseases as a prelude to his course." I wish to protest very strongly against this proposed position of normal psychology in the medical curriculum. Why should the functions of the normal human mind be taught at a period so remote from that at which the student receives instruction in the functions of the normal human body? A course on normal psychology should follow immediately on that of physiology, when the student has the facts of the structure and functions of the sense organs and central nervous system fresh in his mind. Why should psychology stand in the unique position of having its normal and pathological aspects tanght at the same time? Why should "psychological" medicine receive different treatment in the medical curriculum from "somatic" medicine, surgery, or midwifery? As well might the pharmacologist be asked to give some lectures on botany and chemistry, the pathologist some lectures on physiology, chemistry, and anatomy, "as a prelude to his course."

I am, Sir, yours faithfully,

Montagu-square, W., June 20th, 1920. CHARLfis S. MYers.

\section{THE IMPORTANCE OF IMMEDIATE SELF. DISINFECTION.}

To the Editor of THE LANCET.

SiR,-Mr. H. Wansey Bayly's letter published in your last issue will have corrected the wrong impression that the digest of my speech in your previous issue would convey with regard to my remarks about disinfectant centres. No doubt if all those who indulged in promiscuous sexual intercourse could be induced, whatever the weather and the circumstances, to hurry to a disinfectant centre, provided there was one handy, and were there treated by a skilled attendant within one hour of the connexion, many venereal infections would be prevented. But the provision of a sufficient number of these centres bristles with difficulties. In order to comply with the time-limit, which is the vital essence of disinfection, they wculd have to be so numerously provided as to make an adequate provision prohibitive. There remains the danger of espionage and blackmail, which in rulal districts would be very real.

But leaving speculation on one side, the fact remains that the number of disinfectant centres already provided is negligible, while venereal infection is proceeding. For this reason the S.P.V.D. is determined to push forward its policy of instruction in the methods of immediate self-disinfection rather than wait for the universal establishment of disinfectant centres, where at its best the disinfection would be delayed.

June 20th, 1920. I am, Sir, yours faithfully,

\section{THE STANDARDISATION OF COLOUR PERCEPTION.}

To the Editor of THE LANCET.

SIR,-A certain amount of dogmatism is not only condoned, but is even desirable, in a student's textbook. I admit, however, that the statements quoted by Dr. Edridge-Green from the second edition of my "Diseases of the Eye" are open to serious criticism. They have been modified as follows in the third edition :-

"Only those of large experience will gather any useful information from the names given by the subject to various colours, for these are named chiefly by reference to their various brightnesses, and the answers appear to be quite inconsistent. In testing for danger only, it is obvious that the names given to the colours are of value, for if a man repeatedly calls red green or vice versa, he is clearly unsuited to be an engine-driver or look-out man on a ship. ...... Holmgren's wools have been much criticised, but if the tests are properly carried out gross defects of colour vision are easily rease of eren minor defect."
But is Dr. Edridge-Green so opposed to Holmgren's test as his statement that it is "obsolete" would imply" Surely his classification test, which still figures in his latest book, is a direct descendant of the Holmgren test; just as his lantern is a modification - and great improvement - on previous lanterns which had been used for the detection of colour-blindness, his bead test a modification of Sir Wm. Abney's bead test, and his card test a modification of Stilling's test. Of course, the application of a new principle to old tests gives those tests an entirely new meaning. The crux of the situation is whether the principle can be substantiated. In other words, if the scientific evidence is against Dr. EdridgeGreen's theories the whole of the rest of the discussion is beating about the bush.

Dr. Edridge-Green's remark that I am now using his methods is characteristic of his mode of controversy. If to use a lantern for testing colour-vision is using his method, then Holmgren and Donders used his method before he began to write on the subject. But just as I use Nagel's, and Stilling's, and Abney's methods, so I am perfectly prepared to use Dr. Edridge-Green's or anyone else's if they appear to me to help in the elucidation of a very difficult problem.

\section{I am, Sir, yours faithfully,} J. HERBERT PARSONS.

Queen Anne-street, Cavendish-square, W., June 19th, 1920.

\section{To the Editor of THE LANCET.}

SIR,-The papers referred to by Mr. Parsons in the Proceedings of the Royal Society, 1910, can be read by anyone, who can then judge for himself whether the point raised by Lord Rayleigh and supported by Dr. William Watson was "conclusively proved." I am inclined to think that here few would agree with $\mathrm{Mr}$. Parsons. Dr. Edridge-Green read his paper on the theory of vision at the International Medical Congress at Budapest in 1909. This was read, by request, in two sections, the ophthalmological and the physiological. There was not a word of adverse criticism in either section, but the strongest approval. Professor von Tschermak, professor of physiology in Vienna and one of the leading authorities on vision, subsequently wrote to THE LANCET (Oct. 30th, 1909) strongly supporting the theory. I am, Sir, yours faithfully,

Wimpole-street. W., June 21st, 1920. PERCY DUNN.

\section{THE ROLE OF REPRESSION IN THE WAR NEUROSES.}

To the Editor of THE LANCET.

SIR,-With all deference to so eminent an authority as Sir James Crichton-Browne, his remarks (THE LANCET, June 12th, p. 1296) on what he terms the "antirepression method" of dealing with the war neuroses are not in accord with the actual experiences of many psychotherapists. On the contrary, the more one sees of these cases the more one is convinced that amidst the mass of bewildering theories advanced the importance of repression in the production and maintenance of symptoms becomes daily more evident.

Psychotherapists will probably agree with Sir James Crichton-Browne's statement of the concept of repression in the paper referred to, but when he states that patients are told to "keep their miseries ever before them" it may well be asked, Whose teaching this is? It is certainly not that of Dr. W. H. R. Rivers, who cites, only to condemn, the case of an officer with a tendency to dwell overmuch on his war memories.

It is a matter of actual experience that in a majority of the genuine war cases admitted even at this period to neurological hospitals, the patient on being interrogated states that his aim is to banish the war from his memory if he hears it discussed he leaves the room. He says that nothing would induce him to attend such a function as a soldiers' reunion in his town, where he would meet with his old comrades. In short, he is vigorously repressing his war memories. He almost invariably complains of dreaming about the very events he puts out of his mind in the day. time, and this is corroborated by the night staff and by other patients who hear the words shouted in the nightmare.

There is a common misapprehension on the part of those interested in these cases as to the attitude of the psychotherapist towards repression. He wishes the war to be forgotten as much as does the patient, but the difference is 